が，耳下腺組織と接している部では被膜浸潤を示し，一 部耳下腺実質内に浸潤する腫瘍細胞が認められた。 明ら かな癌腫の部分は認められなかったが, 腫瘍全体で個々 の細胞に異型性が認められ浸潤性增殖むみられることか ら, 馬場らの分類 c）に相当する悪性多形性腺腫之診断 した.

\section{7. 䫑稪正外科手術における自己血輸血の応用}

\section{○福田 仁一·都 温彦} 福大医·歯口外

目的：買矯正外科手術はその術式が年々複雑化し, 輸 血を必要とする症例が増加する傾向にある。一般に他人 の血液を輸血すると種々の感染症, 同種免疫学的副作用 などが起こる．これらの点を予防するためには自己血輸 血が最良である，そこで私達は待機的手術が可能である 顎矯正外科手術に対して自己血輸血を応用したので，そ の結果を報告した。

観察症例並びに方法：観察症例は平成 2 年 5 月から平 成 3 年 8 月分の間に罰矯正外科手術を行い，かつ眝血式 自己血輸血を行った男性 4 名 (平均 $23 \pm 4$ 歳), 女性 4 名 (平均 $19 \pm 2$ 歳) の計 8 名である. 顎変形症診断の 内訳は下䅡前突症が男女各 2 例, 下顎後退症が女性 1 例, 下䍛非対称が男性 1 例, 開咬が男女各 1 例であっ た. 術式別症例数では下顎枝矢状骨切りが男女各 3 例, 上顎前菌部蒾槽骨切りと下頢骨体部骨切りの併用が男女 各 1 例であった. 観察方法は全身状態, 採血法, 手術内容, 術前術後の血液検査所見などについて比較・観察した。

結果：眝血式自己輸血に招ける貯血量は開咬の男性の 1 例を除き全て $400 \mathrm{ml}$ であった。眝血期間は最長 36 日, 最短 4 日で, 平均 17 日であった. 眝血方法は凍結保存 が開咬の女性の 1 例に，他は液状保存であった，また血 液検查による $\mathrm{Hb}, \mathrm{Ht}$ 值の推移を見るといずれる術後 4 日目より回復傾向がみられた. しかし出血量と輸血量 が同じものでは術後 14 日には術前値に戻るが, 出血量 の多いあのでは術前值にまで回復しなかった. 網状赤血 球の推移では出血量が輸血量を上回ったものでは増加が 見られた。

今回の観察から，額矯正外科手術においては自己血輸 血が有用であることが確認された．また手術可能な基準 を満たした下顎枝矢状骨切り術の症例においても，体重 や $\mathrm{Hb}, \mathrm{Ht}$ の值の低いむのでは突発の出血を考えると 眝血を行っておくほうが良いと思われた。
一ポスターセッションー

\section{1. 二種界面活性剂の短時間接触における殺菌効果}

\section{○東泉·大住 伴子·黒木賀代子} 九歯大 $\cdot$ 歯薬理

【目的】界面活性剂は, 表面張力, 界面張力を低下さ せると共に殺菌作用を示すが，その殺菌作用は界面活性 の強さと必ずしむ並行せず，作用機序としては, 細胞膜 の特にリン脂質と反応して膜を障害し，内容物の漏出あ るいは菌体内酵素系の阻害をすることによるといわれて いる，消毒薬として用いる場合には，その薬物が人体あ るいは器具などに対して，皮庙刺激性，金属腐触性など を示さず，また，手指消毒の現状等を考慮すると，数分 以内に効果を発現することが要求される. これらのこと から, 今回, 従来のカチオン界面活性剂に比べ生体に対 する刺激がきわめて少なく，かつ良好な洗浄力と広範囲 の殺菌力を持つといわれている界面活性剤である $\mathrm{CAE}$ (Na-ココイル-L-アルギニンェチルエステル $\mathrm{DL}-ヒ^{\circ}$ ロリドンカルボン酸塩）と，代表的なカチオン界面活性 剂である塩化ベンザルコニウム（BKC）の，2つの界 面活性剂について，特に短時間における殺菌効果を経時 的に観察した.【方法】最終濃度が $10^{6} \mathrm{cells} / \mathrm{ml}$ の菌液 を分注した試験管に希釈した消毒薬を加え， $20 \pm 2{ }^{\circ} \mathrm{C}$ において $0.5,1,2,3,4,5,30$ および 60 分後に BHI 寒天培地に接種し, 24 時間 $37^{\circ} \mathrm{C}$ にて培養後, 菌の発育 の有無により殺菌効果を判定した.【結果】二種界面 活性剂を接触時間が 0.5 分の場合で比較すると, $E$. coli，S. aureus に対しては BKC の方が低濃度で殺菌作 用を示した. 一方, 30 分〜 60 分になると CAE の殺菌 効果が現れ，E． coliでは BKCを上まわり，S. aureus では BKC と同じ濃度で殺菌作用を示した。.また， $B$. subtilis に対しては，2 分以降で $\mathrm{BKC}$ が CAE よりやや 強い殺菌作用を示したが，その濃度はBKC の通常使用 する濃度の約 7 倍を要した。これらの菌に対して BKC の方が速効性があるという点では，手指の消毒薬として 優れているといえるが，接触時間を延長すれば CAE は BKC とほぼ同等の消毒効果を現しうると考えられた。 